\title{
HUBUNGAN ANTARA SELF ESTEEM DENGAN PENYESUAIAN DIRI SEBAGAI PERAN IBU RUMAH TANGGA PADA IBU BERHENTI BEKERJA DI JAKARTA
}

\author{
Yuke Riana Devi ${ }^{1}$, Endang Fourianalistyawati ${ }^{2)}$ \\ Fakultas Psikologi Universitas YARSI \\ 1yukeoke.31@gmail.com, 2endangfouriana@gmail.com
}

\begin{abstract}
Mother stopped working, and chose to become a housewife as may be necessary to adjust themselves well, such as nurturing and caring for the child, completing household chores well, and socialize with the environment around the house. Adjustment is done well will be associated with the formation of a good self esteem. This study aims to determine the relationship between self-esteem with the adjustment to the role of a housewife mother stopped working in Jakarta. The sampling technique in this research using accidental sampling technique by taking the subject as much as 70 housewives in Jakarta. Data analysis techniques used in this study is the Pearson Product Moment Correlation technique. The results of this study indicate that there is a significant positive relationship between self-esteem with the adjustment to the role of a housewife mother stopped working in Jakarta, $(r=0.608, p=0.000)$. It can be said that the higher the mother's self-esteem, the better the ability to adjust himself to be a housewife. Conversely, the lower the mother's self-esteem, the worse the ability to adjust himself to be a housewife.
\end{abstract}

Keywords: Self Esteem, Adjustment, Housewife, Mother Stopped Working

\section{ABSTRAK}

Ibu yang berhenti bekerja, dan memilih menjadi ibu rumah tangga dianggap perlu melakukan penyesuaian diri dengan baik, seperti mengasuh dan merawat anak, menyelesaikan tugas-tugas rumah tangga dengan baik, dan bersosialisasi dengan lingkungan sekitar rumah. Penyesuaian diri yang dilakukan secara baik akan terkait dengan terbentuknya self esteem yang baik. Penelitian ini bertujuan untuk mengetahui hubungan antara self esteem dengan penyesuaian diri terhadap peran sebagai ibu rumah tangga pada ibu berhenti bekerja di Jakarta. Teknik pengambilan sampel pada penelitian ini menggunakan teknik accidental sampling dengan mengambil subjek sebanyak 70 ibu rumah tangga di Jakarta. Teknik analisis data yang digunakan dalam penelitian ini adalah teknik Korelasi Pearson Product Moment. Hasil penelitian ini menunjukkan bahwa terdapat hubungan positif yang signifikan antara self esteem dengan penyesuaian diri terhadap peran sebagai ibu rumah tangga pada ibu berhenti bekerja di Jakarta, $(r=0,608 p=0,000)$. Dapat dikatakan bahwa semakin tinggi self esteem ibu maka semakin baik kemampuan penyesuaian dirinya untuk menjadi ibu rumah tangga. Sebaliknya, semakin rendah self esteem ibu, maka semakin buruk kemampuan penyesuaian dirinya untuk menjadi ibu rumah tangga.

Kata Kunci: Self Esteem, Penyesuaian Diri, Ibu Rumah Tangga, Ibu yang Berhenti Bekerja

\section{PENDAHULUAN}

Perubahan zaman mengubah pandangan tentang kemampuan ibu untuk memperjuangkan hak dan kewajibannya. Selain harus menjadi sosok ibu bekerja di kantor, juga menjadi ibu yang baik untuk keluarganya di rumah, terutama untuk suami dan anak-anaknya. Di kota besar seperti Jakarta, banyak para ibu yang menunjukkan eksistensi dirinya dengan menjadi wanita karir yang sukses. Pendapatan pribadi yang diterima setiap bulan merupakan bentuk kebanggaan sekaligus identitas sebagai individu yang lebih mandiri (Ibadiah, 2016).
Belakangan ini, ibu bekerja di perusahaan tak juga lepas dari berbagai permasalahan dan tuntutan kerja yang banyak. Profesionalitas dalam berkerja terkadang menjadi sebuah permasalahan yang tidak disadari. Fenomena ini memberikan dampak positif dan negatif. Dampak positif yang dikemukakan oleh Lim (dalam Wardani, 2015), menyatakan bahwa ibu yang memprioritaskan bekerja untuk keluarga akan meningkatkan kepercayaan diri, kompetensi, dan rasa kebanggaan pada perannya sebagai ibu pekerja. Selanjutnya, ibu bekerja tidak lagi dianggap sebagai seseorang yang semata-mata tergantung 
pada penghasilan suaminya, melainkan ibu bekerja dapat ikut membantu berperan dalam meningkatkan penghasilan keluarga sebagai salah satu pemenuhan kebutuhan keluarga yang bermacam-macam (Wicaksono, 2011).

Keputusan untuk menjadi ibu bekerja tidak semudah yang dipikirkan, selalu ada yang dikorbankan. Selain itu, konsekuensi harus diperhatikan karena peran ibu tidak lagi sepenuhnya ada di rumah. Konsekuensi negatif yang terjadi akibat dari ibu yang bekerja antara lain: dapat meningkatkan risiko terjerumusnya anak-anak kepada hal yang negatif, seperti tindak kriminal yang dilakukan sebagai akibat dari kurangnya kasih sayang yang diberikan orangtua, khususnya Ibu terhadap anak-anaknya (Wicaksono, 2011). Selain itu, pada suami memiliki perasaan tersaingi, dan tidak terpenuhi hak-haknya sebagai suami. Pada rumah tangga, memiliki risiko kegagalan rumah tangga terkait ketidakmampuan istri mengurus rumah tangga atau sibuk berkarir. Pada masyarakat, yaitu bertambahnya pengangguran untuk pria dikarenakan wanita mengambil alih pekerjaannya. Hal ini, juga terkait dengan permintaan perusahaan, dimana lebih memilih wanita dibandingkan pria karena upah yang murah dan anggapan wanita tidak terlalu banyak menuntut dan mudah diatur (Wicaksono, 2011).

Pernyataan tersebut dijelaskan juga oleh Tjaja (dalam Wicaksono, 2011), yang mengungkapkan bahwa kecenderungan ibu untuk bekerja di luar rumah akan membawa konsekuensi sekaligus berbagai dampak sosial, antara lain meningkatnya kenakalan remaja akibat kurangnya perhatian orang tua, makin longgarnya nilai-nilai ikatan perkawinan/keluarga dan lain-lain.

Kewajiban seorang ibu bekerja menjadi berlipat ganda terlebih jika sudah memiliki keturunan. Tak sedikit para ibu mengaku mengalami dilema ketika dihadapkan kepada dua pilihan besar, yaitu menjadi seorang istri serta ibu di dalam rumah, atau tetap bekerja demi memenuhi kebutuhan hidup sehari-hari (Ibadiah, 2016). Oleh karena itu, perannya sebagai ibu rumah tangga dibutuhkan di rumah. Kondisi tersebut dapat mempengaruhi ibu untuk berhenti bekerja.

Seorang ibu akan melakukan hal-hal terbaik untuk keluarganya, termasuk ketika harus berhenti bekerja dengan alasan ingin menyejahterakan keluarganya (Ibadiah, 2016). Biasanya, faktor yang paling dominan mendukung ibu untuk berhenti bekerja adalah jumlah anak. Semakin banyak anak, kemungkinan si ibu berhenti bekerja menjadi semakin besar. Selain itu, tidak adanya pengasuh atau orang yang dipercaya untuk menjaga anak juga berperan dalam pengambilan keputusan ibu untuk berhenti. Selanjutnya, adalah permintaan dari suami, dan terakhir keadaan ekonomi keluarga sudah mulai cukup dengan hanya suami yang bekerja.

Menurut Gardenswartz (dalam Koran, 2010), diperkirakan 5,6 juta wanita di California memilih menjadi ibu rumah tangga dan tinggal di rumah. Data ini menunjukkan ada kenaikan 22 persen dari tahun 1994. Sedangkan, populasi wanita di Jakarta, Indonesia pada tahun 2012 ditunjukkan dari Badan Pusat Statistik (BPS) dengan spesifikasi penduduk wanita usia dewasa muda yang tinggal di rumah sebesar 2.579.953 jiwa. Hal ini, menunjukkan masih banyak wanita Indonesia yang memilih untuk tetap di rumah atau menjadi seorang ibu dengan kondisi yang tidak bekerja.

Pentingnya fungsi ibu di rumah patut untuk disadari, menjadi ibu rumah tangga adalah suatu pekerjaan yang sudah menjadi kodrat mulia seorang perempuan yang dilakukan seumur hidup selama menikah. Ibu rumah tangga adalah wanita yang lebih banyak menghabiskan waktunya di rumah, mempersembahkan waktunya untuk menjaga anak-anak dan mengasuh menurut pola-pola yang diberikan masyarakat (Dwijayanti, 1999).

Seorang ibu pada umumnya seringkali mendapatkan kepuasan dari pekerjaan rumah tangga untuk anggota keluarga, karena aktifitas ini adalah simbol dari cinta (Ponzetti, 2013). Menurut Sukmana (1995), tugas ibu rumah tangga dalam kehidupan keluarga yaitu mengatur tata laksana rumah tangga. Sehingga kondisi keluarga menjadi teratur dan rapi. Ibu rumah 
tangga dituntut untuk mengerjakan berbagai macam pekerjaan rumah tangga dalam setiap harinya, dengan jam kerja yang tidak terbatas karena berlangsung terus-menerus.

Tuntutan dan kewajiban di rumah sering kali menimbulkan stres bagi ibu. Peran ibu rumah tangga terkadang dianggap tidak mampu mendukung perkembangan pribadi, karena tidak dapat memperluas wawasan, sehingga peran ini dianggap tidak berfungsi. Berbagai macam tuntutan ibu rumah tangga dapat membuat ibu merasa tertekan, merasa terancam, dan kesulitan menghadapi konflik dalam penyelesaian tugas rumah tangga. Tuntutan tugas rumah tangga tersebut sering dianggap ibu melebihi sumber daya yang dimilikinya. Karena semua tugas rumah tangga dikerjakan seorang diri yang membutuhkan keterampilan, waktu, dan tenaga yang banyak. Ketidakseimbangan antara tuntutan dengan sumber daya yang dimiliki menyebabkan ibu berada dalam kondisi stres yang dirasakan membahayakan kesejahteraan ibu (Maisya, 2014).

Oleh karena itu, dibutuhkan penyesuaian diri pada ibu rumah tangga. Penyesuaian merupakan proses dinamis yang bertujuan untuk mengubah tingkah laku individu agar terjadi hubungan yang lebih sesuai antara individu dengan lingkungannya (Haber \& Runyon, dalam Indrawati \& fauziah, 2012). Setelah berhenti bekerja, dalam menjalankan perannya sebagai ibu rumah tangga, ibu diharapkan dapat melakukan penyesuaian diri dengan baik seperti, mampu dalam bersosialisasi dengan lingkungan sekitar rumah, menyelesaikan tugas-tugas rumah tangga dengan baik,dan memelihara serta mengasuh anak.

Penyesuaian diri merupakan suatu kemampuan seseorang untuk memenuhi tuntutan dari lingkungannya. Seseorang dapat melakukan penyesuaian diri sosial dengan cara memahami berbagai aturan dalam lingkungan sosialnya. Hal ini mempengaruhi perilaku individu dalam melakukan interaksi sosial (Calhoun, 2001). Penerimaan diri di lingkungan baru dapat mengubah keyakinan diri seseorang. Apalagi dengan statusnya yang berubah dari ibu bekerja menjadi ibu rumah tangga seutuhnya di rumah, maka penyesuaian diri penting untuk dilakukan. Penyesuaian diri yang baik diprediksi berhubungan dengan self esteem pada ibu rumah tangga.

Berdasarkan hasil penelitian Desiningrum (2012), diketahui bahwa self esteem memberikan peranan sekitar $41 \%$ terhadap aspek fungsi sosial dari penyesuaian diri, memberikan peranan sebesar $78 \%$ terhadap aspek moral, dan $41 \%$ terhadap aspek kesehatan fisik. Self esteem dan penyesuaian diri merupakan proses pertumbuhan individu dalam rangka penyesuaian dalam dunia sosial untuk menahan dan mengendalikan diri. Pertumbuhan diri ketika mengalami proses penyesuaian sosial, akan berfungsi seperti pengawas yang mengatur kehidupan sosial dan kejiwaan.

Penelitian sebelumnya yang peneliti temukan sudah ada yang menghubungkan dua atau salah satu dari variabel dari self esteem dan penyesuaian diri. Namun, penelitian untuk subjek ibu rumah tangga yang telah berhenti bekerja belum peneliti temukan. Hal ini membuat peneliti tertarik untuk melihat adakah hubungan antara self esteem dengan penyesuaian diri terhadap peran sebagai ibu rumah tangga pada ibu dewasa muda yang berhenti bekerja di Jakarta.

\section{Self Esteem}

Heatherton dan Wyland (2003) mengatakan self esteem adalah sikap tentang diri dan berhubungan dengan keyakinan pribadi tentang keterampilan, kemampuan, hubungan sosial, dan hasil masa depan. Sedangkan Harper (dalam, Hermawati, 2011) memberikan pengertian self esteem sebagai penilaian yang dipengaruhi oleh sikap, interaksi, penghargaan dan penerimaan orang lain terhadap individu. Leary, Schreindofer \& Haupt (dalam Baron \& Byrne, 2003) menjelaskan bahwa self esteem yang tinggi memiliki konsekuensi yang positif sementara self esteem yang rendah memiliki efek negatif. Evaluasi diri negatif dihubungkan dengan keterampilan sosial yang tidak memadai seperti kesepian, depresi, dan untuk bekerja dapat memberikan hasil buruk yang menyebabkan kegagalan. Sebaliknya individu dengan self 
esteem yang tinggi mampu bertahan ketika menghadapi kegagalan yang dapat meningkatkan kesuksesan di masa yang akan datang (Baron \& Bryne 2003). Berdasarkan uraian di atas, dapat disimpulkan bahwa self esteem adalah penilaian individu terhadap dirinya sendiri yang dipengaruhi oleh hasil interaksinya dengan orang-orang yang penting dilingkunganya serta dari sikap, penerimaan, penghargaan, dan perlakuan orang lain terhadap dirinya.

Terdapat tiga komponen utama dalam self esteem menurut Heatherton dan Polivy (1991), yaitu dari:

(1) Performance. Performance mengacu pada pengertian seseorang tentang kompetensi umum dan termasuk kemampuan intelektual, seperti kinerja sekolah, kapasitas regulasi diri, percaya diri, dan self agency. Seseorang yang tinggi dalam self esteem performance percaya bahwa mereka pintar dan mampu.

(2) Social. Self esteem sosial mengacu pada bagaimana seseorang percaya orang lain memandang diri mereka. Mereka sangat memperhatikan persepsi daripada realitas. Jika seseorang percaya dengan orang lain, terutama pada orang lain yang signifikan menilai dan menghormati mereka, seseorang akan memiliki self esteem sosial yang tinggi. Sebaliknya, orang yang memiliki self esteem sosial yang rendah sering mengalami kecemasan sosial dan kesadaran diri yang tinggi di masyarakat. Mereka sangat memperhatikan citra mereka dan merasa khawatir tentang bagaimana orang lain mereka.

(3) Physical. Fisik diri mengacu pada bagaimana orang melihat tubuh fisik mereka, dan mencakup hal-hal seperti keterampilan atletik, daya tarik fisik, citra tubuh, serta stigma fisik dan perasaan tentang ras dan etnis.

\section{Penyesuaian Diri}

Setiap orang pasti akan mengalami masalah dalam mencapai tujuan hidupnya dan dalam hal ini membutuhkan suatu proses yang dinamakan penyesuaian diri (Haber \& Runyon, dalam Sitorus \& Wiryosutomo, 2013). Penyesuaian diri merupakan proses dinamis yang bertujuan untuk mengubah tingkah laku individu agar terjadi hubungan yang lebih sesuai antara individu dengan lingkungannya (Haber \& Runyon, dalam Indrawati \& Fauziah, 2012). Dapat disimpulkan juga, bahwa penyesuaian diri merupakan suatu kemampuan yang dimiliki seseorang untuk memenuhi tuntutan dari lingkungannya.

Penyesuaian diri merupakan faktor yang penting dalam menyelaraskan kebutuhan pribadi dengan tuntutan sekitar agar mendapat kepuasan dalam menjalani hubungan antara dirinya dengan lingkungan (Putri, 2010). Penyesuaian diri merupakan proses yang meliputi respon mental dan perilaku yang merupakan usaha individu untuk mengatasi dan menguasai kebutuhankebutuhan dalam dirinya, keteganganketegangan, frustasi, dan konflik-konflik agar terdapat keselarasan antara tuntutan dari dalam dirinya dengan tuntutan atau harapan dari lingkungan (Schneiders, 1964).

Manusia dituntut untuk menyesuaikan diri baik dengan lingkungan sosialnya maupun dengan lingkungan alam disekitarnya. Kehidupan manusia secara alamiah juga mendorong manusia untuk terus-menerus menyesuaikan diri. Penyesuaian diri merupakan modifikasi dari sikap dan perilaku dalam menghadapi tuntutan lingkungan secara efektif (Corsini, 2002). Penyesuaian diri juga diperlukan dalam upaya membina hubungan yang memuaskan antara individu dengan lingkungannya (Davidoff, 1991).

Dari beberapa definisi mengenai penyesuaian diri dapat disimpulkan bahwa penyesuaian diri adalah suatu usaha yang dilakukan oleh seseorang untuk mengatasi tuntutan-tuntutan dari lingkungannya agar tercipta keselarasan serta hubungan yang memuaskan antara individu dengan lingkungannya.

Haber dan Runyon (dalam Sitorus \& Wiryosutomo, 2013) mengungkapkan bahwa terdapat beberapa aspek penyesuaian diri, antara lain:

(1) Persepsi yang akurat terhadap realita. Mengenali konsekuensi dari tindakan yang dilakukan dan mengatur tingkah laku sesuai konsekuensi tersebut.

(2) Kemampuan untuk mengatasi stres dan kecemasan. Coping terhadap stres 
atau kecemasan akan terjadi apabila kita mau mengakui bahwa pencapaian tujuan dalam hidup akan memberikan arah dan jalan serta membuat seseorang dapat lebih bertahan dari keinginan, kekalahan yang tidak bisa dihindari, rasa frustrasi dan stres yang mungkin terjadi.

(3) Self-image yang positif. Penilaian diri yang seseorang lakukan harus bersifat positif dan negatif. Seseorang tidak boleh terjebak pada satu penilaian saja, terutama penilaian yang tidak diinginkan, seseorang harus berusaha memodifikasi penilaian tersebut menjadi perubahan yang lebih baik. Seseorang harus mampu mengakui kelemahan dan kelebihannya. Jika seseorang mampu mengetahui dan memahami dirinya dengan cara yang realistik, maka ia akan mampu mengembangkan potensi yang ada di dalam dirinya secara penuh.

(4) Kemampuan untuk mengungkapkan perasaan. Seseorang mampu merasakan dan mengekspresikan keseluruhan emosi secara realistik dan tetap berada di bawah kontrol. Masalah-masalah dalam pengungkapan perasaan adalah seperti kurangnya kontrol atau adanya kontrol berlebihan. Kurangnya kontrol akan menyebabkan ekspresi emosi yang berlebihan sedangkan kontrol berlebihan dapat menyebabkan seseorang kurang peka terhadap lingkungannya sehingga kedua hal ini dapat menjadi masalah dalam penyesuaian diri.

(5) Hubungan interpersonal yang baik. Manusia pada dasarnya adalah makhluk sosial. Sejak berada di dalam kandungan, manusia selalu tergantung pada orang lain untuk memenuhi kebutuhan hidup seperti kebutuhan fisik, sosial, dan emosi. Seseorang yang dapat menyesuaikan diri dengan baik mampu menciptakan hubungan yang saling menguntungkan dengan orang lain satu sama lain.

\section{Ibu Rumah Tangga}

Kebanyakan wanita telah mengetahui bahwa masyarakat mengharapkan mereka menjadi istri atau ibu sehingga dalam waktuwaktu yang lalu nilai-nilai yang dipegang kalangan menengah mengharuskan wanita mengurus rumah tangga. Karena ibulah yang biasanya bertanggung jawab atas keberangkatan anak ke sekolah dan keberangkatan suami ke pekerjaan pada waktunya (Wolfman, 1988).

Menurut Mappiare (dalam Ananda, 2013) ibu rumah tangga menurut konsep tradisional adalah wanita yang mempersembahkan waktunya untuk memelihara dan melatih, mengasuh anakanak menurut pola-pola yang dibenarkan oleh masyarakat. Jadi wanita yang tidak bekerja adalah wanita yang mempersembahkan waktunya untuk mengurus, memelihara rumah (keluarga) tanpa suatu aktivitas atau pekerjaan di luar rumah. Atau dengan kata lain wanita yang tidak bekerja adalah wanita yang hanya menjalankan fungsinya sebagai ibu rumah tangga yang lebih banyak menghabiskan waktunya di rumah tanpa terkait pekerjaan lain di rumah. Kegiatan ibu rumah tangga yang berpusat pada kegiatan melayani dalam arti kata yang luas. Termasuk disini mendidik, merawat, mengatur waktu untuk dinikmati bersama-sama oleh anggota keluarga (Munandar, dalam Ananda, 2013). Ibu yang tidak bekerja disini adalah wanita yang hanya menjalankan fungsinya sebagai ibu rumah tangga, yang lebih banyak menghabiskan waktunya di rumah tanpa terikat pekerjaan di luar rumah.

Pada penelitian ini, peneliti mengkategorikan Ibu muda sebagai pilihan subjek penelitian. Menurut Papalia, Olds dan Feldman (2009) pada usia 20-40 tahun termasuk dalam tahapan perkembangan dewasa muda. Pada masa dewasa muda ini, individu baru saja mengalami masa transisi fisik, kognitif, dan peran sosial (Santrock, 2005) dari remaja menjadi individu dewasa yang utuh. Masa dewasa muda merupakan periode saat individu memulai langkahnya menjadi individu yang mandiri. Peneliti sendiri memutuskan untuk menggunakan rentang usia dewasa muda dari 20 hingga 40 tahun. Pada rentang usia dewasa ini, seseorang sedang menjalani perkuliahan, bekerja, atau sudah membentuk keluarga (Hoyer dan Roodin, dalam Prawono, 2012). Ketiga hal ini membutuhkan sosialisasi dengan lingkungan sekitar sehingga penampilan fisik pun turut berperan. 
Erikson (dalam, Papalia, Olds \& Feldman., 2009) menjelaskan bahwa usia dewasa muda memiliki tugas perkembangan menyelesaikan krisis intimasi vs. isolasi. Pada tahap ini individu merasakan awal mula perpisahan dengan orang tua. Dewasa muda mulai hidup sendiri dan mencari pekerjaan. Orang tua biasanya melepaskan sedikit tanggung jawab atas individu sehingga individu mencari sosok lain untuk merasakan intimasi. Pada saat inilah individu mencari pasangan. Menurut Erikson, intimasi yang baik dilandasi dengan hubungan yang bersifat saling pengertian, komitmen, kejujuran, dan saling mempercayai. Individu yang telah berhasil menemukan identitas diri yang solid pada masa remaja, akan mampu mengatasi krisis ini dan dapat menciptakan hubungan yang intim dan harmonis. Bagi dewasa muda yang tidak dapat melalui krisis ini dengan baik akan merasakan isolasi.

Self esteem yang dimaksud pada penelitian ini adalah penghargaan diri ibu terhadap perannya sebagai ibu rumah tangga setelah berhenti bekerja, terhadap diri sendiri dan kondisi baru yang tidak bekerja lagi seperti, bagaimana cara pandang ibu dalam menilai kesibukanya sekarang dengan apa yang telah ia lakukan. Beberapa penelitian yang telah dilakukan pada beberapa negara di dunia (Markus \& Kitamaya, 1994; Markus \& Kitamaya, 1991) menemukan bahwa self esteem pada masyarakat Jepang dan Amerika ternyata dibedakan oleh budaya setempat. Menurut Maslow (dalam Ananda, 2013), kebutuhan akan self esteem merupakan salah satu kebutuhan dasar manusia yang mendorong orang untuk mendapatkan pengakuan serta penghargaan dari orang lain.

Penyesuaian diri merupakan proses dinamis yang bertujuan untuk mengubah tingkah laku individu agar terjadi hubungan yang lebih sesuai antara individu dengan lingkungannya (Haber \& Runyon, dalam Indrawati \& Fauziah, 2012). Dapat dikatakan bahwa penyesuaian diri merupakan suatu kemampuan seseorang untuk memenuhi tuntutan dari lingkungannya. Seseorang dapat melakukan penyesuaian diri dalam aspek fungsi sosial, dengan cara memahami berbagai aturan dalam lingkungan sosialnya, dan hal ini mempengaruhi perilaku individu dalam melakukan interaksi sosial (Calhoun, 2001). Pada penelitian ini, peneliti ingin melihat bagaimana penyesuaian diri terhadap peran sebagai ibu rumah tangga dengan berbagai macam aktifitas yang ibu sering lakukan di rumah. Peran ibu di rumah sangat dibutuhkan biasanya dalam mengurus anak dan pekerjaan rumah tangga.

Tuntutan utama ibu rumah tangga adalah mengerjakan pekerjaan rumah. Pekerjaan rumah adalah tugas yang berbeda jumlah dan jenisnya yang tergantung pada ukuran rumah tangga, komposisi dan harapan budaya di rumah tangga tersebut. Jika anak-anak hadir dalam rumah tersebut, maka merawat anak adalah tugas rumah tangga utama yang membawa serta berbagai tugas rumah tangga lainnya (Ponzetti, 2013). Merawat orang tua pada umumnya juga tanggung jawab tambahan ibu di rumah.

Biasanya ibu yang mampu, menyewa asisten rumah tangga untuk melakukan pekerjaan rumah tangga atau untuk merawat yang muda atau tua. Tetapi, pada kenyataannya para ibu rumah tangga melakukan tugas ini sendiri tanpa imbalan. Tugas rutin rumah tangga yang diperlukan untuk mempertahankan individu dan memelihara rumah termasuk menyiapkan makanan, membersihkan rumah, berbelanja dan mencuci pakaian dikerjakan sendiri oleh ibu (Ponzetti, 2013).

Masyarakat pada umumnya, khususnya ibu, mendapatkan kepuasan dari pekerjaan rumah tangga untuk anggota keluarga, karena aktifitas ini adalah simbol dari cinta (Devavir, dalam Ponzetti, 2013). Dalam waktu yang sama, pekerjaan rumah tangga yang berlangsung terus menerus dan diturunkan oleh istri kepada anak perempuanya dapat yang dapat dianalisis sebagai bagian dari sistem besar dalam ketidaksetaraan gender.

Tugas-tugas tersebut di atas cenderung padat dan wajib dilakukan hingga terasa membosankan, dan para ibu yang memiliki tanggung jawab itu. Sehingga, ibu juga jarang sekali ibu menyibukkan diri pada kegiatan tambahan seperti berkebun dan perawatan halaman (Ponzetti, 2013). 
Self esteem dimiliki oleh setiap manusia. Perasaan ingin dihargai seperti dalam hirarki Maslow, itu semua dapat terjadi pada setiap manusia pada umumnya. Terlebih lagi sosok ibu, wanita yang selalu punya sisi kelembutan dalam melakukan tugasnya di rumah mengurus anak memasak dan menjamu suami.

Menjadi seorang ibu tidaklah mudah, apalagi di zaman sekarang banyak ibu yang mengorbankan karirnya demi keluarganya, anak anaknya, serta suaminya, keputusan tersebut menjadi sebuah dilema besar dalam hidupnya. Sosok ibu juga memiliki tuntutan kewajiban di rumah yang tidak semudah yang kita lihat dan sering kali menimbulkan stres bagi ibu (Smet, 1994).

Dalam penelitian ini, peneliti ingin mengetahui hubungan antara dua variabel yaitu self esteem dan penyesuaian diri. Self esteem sangat erat hubunganya dengan bagaimana proses penyesuaian diri selanjutnya pada seseorang. Penelitian Desiningrum (2012) tentang hubungan antara self esteem dan penyesuaian diri pada pensiunan TNI $\mathrm{AD}$, menunjukkan self esteem memberikan peranan sekitar $41 \%$ terhadap aspek fungsi sosial dari penyesuaian diri, self esteem juga memberikan peranan sebesar $78 \%$ terhadap aspek moral, dan $41 \%$ terhadap aspek kesehatan fisik.

Penyesuaian diri seseorang dapat dipengaruhi oleh kondisi psikologisnya, termasuk kepribadiannya (Lazarus \& Folkman dalam Martin \& Osborne, 1997). Para ibu dapat memiliki penilaian tersendiri terhadap diri setelah mengalami perubahan kondisi setelah berhenti bekerja, yang menyangkut keadaan self-esteem-nya. Self esteem sebagai salah satu dimensi kepribadian menunjukkan penilaian individu terhadap dirinya, yang nantinya akan menghasilkan bagaimana penerimaan dan penghargaan diri (Coopersmith, 1967).

Berdasarkan ulasan di atas peneliti berasumsi bahwa self esteem dan penyesuaian diri merupakan proses pertumbuhan kemampuan individu dalam rangka penyesuaian dalam dunia sosial untuk menahan dan mengendalikan diri. Pertumbuhan kemampuan diri ketika mengalami proses penyesuaian sosial akan berfungsi seperti pengawas yang mengatur kehidupan sosial dan kejiwaan.

\section{METODE PENELITIAN}

Pada penelitian ini, peneliti menggunakan pendekatan kuantitatif dengan jenis penelitian korelasional dan desain penelitian asosiatif. untuk mencari hubungan antara satu variabel dengan variabel lain.

Populasi dalam penelitian ini adalah ibu rumah tangga yang telah berhenti bekerja berumur antara 20 sampai 40 tahun yang berlokasi di wilayah Jakarta. Alasan praktis peneliti memilih wilayah Jakarta sebagai tempat penelitian yang dituju karena mudah untuk mencari subjek ibu bekerja karena tuntutan kebutuhan finansial di Jakarta lebih tinggi sehingga kemungkinan ibu untuk bekerja dan berhenti lebih besar.

Penelitian ini menggunakan subjek ibu rumah tangga yang telah berhenti bekerja berusia dari 20-40 tahun. Pada rentang usia dewasa ini, seseorang sedang menjalani kehidupan perkuliahan, bekerja, atau sudah membentuk keluarga (Hoyer dan Roodin, 2009). Adapun syarat lainnya adalah: (1) telah menikah dan menjadi ibu rumah tangga di rumah, (2) telah berhenti bekerja, dan (3) telah memiliki anak.

Teknik pengambilan sampel yang digunakan dalam penelitian ini yaitu teknik accidental sampling. Peneliti menghubungi orang-orang yang peneliti kenal dan meminta kesediaan mereka untuk membantu peneliti dalam menyebar kuesioner serta kuesioner dalam bentuk link pada orangorang yang dikenal. Walaupun demikian, teknik pengambilan sampel tersebut membuat generalisasi dari penelitian ini terbatas hanya pada kelompok yang sesuai dengan kelompok dalam penelitian ini. Lokasi pengambilan sampel adalah di wilayah Jakarta, dengan pertimbangan efisiensi dalam menjalankan penelitian. Total subjek yang digunakan dalam penelitian ini adalah 70 orang.

Alat ukur yang digunakan peneliti untuk mengukur self-esteem pada penelitian ini yaitu The State Self Esteem Scale yang diadaptasi oleh peneliti dengan melalui tahap menerjemahkan alat ukur kepada ahli 
penerjemah lalu expert judgment dengan 2 dosen yang berkompeten di bidangnya. Berdasarkan skala state self esteem oleh Heatherton dan Polivy (1991). Alat ukur ini terdiri dari 20 aitem. Peneliti menggunakan adaptasi alat ukur dari Heatherton dan Polivy (1991) karena skala ini lebih spesifik mengukur tentang tiga komponen diantaranya performance, social, dan physical. Salah satu diantaranya berhubungan dalam mengukur self esteem pada penelitian ini yaitu mengukur penyesuaian diri dalam lingkungan sosialnya.

Dalam teknik skoring peneliti menggunakan skala likert, subjek memberikan respon seperti $(1=$ sangat tidak sesuai, $2=$ tidak sesuai, $3=$ sesuai $4=$ sangat sesuai). Tidak ada jawaban benar atau pun salah sehingga subjek harus menjawab sesuai dengan respon sesuai atau tidak sesuai di setiap item. Selain itu, dalam kuisioner terdapat aitem yang favorable (yang tidak dibalik dalam proses skoring/sesuai) atau unfavorable (yang harus dibalik dalam proses skoring/pernyataan tidak sesuai). Skor tinggi menunjukkan subjek memiliki self esteem tinggi, sebaliknya skor rendah menunjukkan subjek memiliki self esteem rendah. Validitas state self-esteem scale memiliki nilai item correlated $>0,20$ dianggap valid. 20 item dinyatakan valid dengan koeff. $a=0.92$.

Kemudian, untuk mengukur penyesuaian diri peneliti menggunakan alat ukur penyesuaian diri yang dimodifikasi oleh peneliti dari Hidayanti (2014), dengan mengacu kepada aspek-aspek dari Haber \& Runyon (dalam Sitorus \& Wiryosutomo, 2013), yaitu persepsi yang akurat terhadap realita, kemampuan untuk mengatasi stres dan kecemasan, self-image yang positif, kemampuan untuk mengungkapkan perasaan, dan hubungan interpersonal yang baik. Aspek dan indikator peneliti sesuaikan dengan peneliti sebelumnya dan untuk aitem peneliti buat dengan peran sebagai ibu rumah tangga.

Dalam teknik skoring, peneliti menggunakan skala likert yaitu seperti (1= sangat tidak sesuai, $2=$ tidak sesuai, $3=$ sesuai $4=$ sangat sesuai). Selain itu, dalam kuesioner terdapat aitem yang favorable yaitu berisi konsep perilaku yang sesuai atau mendukung atribut yang diukur dan ada aitem unfavorable yaitu yang isinya bertentangan atau tidak mendukung ciri perilaku yang dikehendaki oleh indikator keperilakuanya (Azwar, 2013).

\section{HASIL DAN PEMBAHASAN}

Hasil dari penelitian ini adalah terdapat hubungan positif yang signifikan antara self esteem dan penyesuaian diri terhadap peran sebagai ibu rumah tangga pada ibu dewasa muda yang berhenti bekerja dengan $r=0,608$ dan $p=0,000(p<0,005)$. Semakin tinggi self esteem ibu rumah tangga maka semakin baik kemampuan penyesuaian dirinya untuk menjadi ibu rumah tangga di rumah. Sebaliknya, semakin rendah self-esteem ibu rumah tangga, maka semakin buruk kemampuan penyesuaian dirinya untuk menjadi ibu rumah tangga. Artinya, untuk mereduksi stres akibat keadaan ibu rumah tangga yang sudah tidak bekerja lagi, dibutuhkan self esteem yang tinggi agar ibu dapat melakukan penyesuaian diri dengan baik.

Hasil penelitian ini juga sejalan dengan penelitian yang dilakukan Desiningrum (2012), tentang Hubungan self esteem dengan penyesuaian diri terhadap masa pensiun pada pensiunan Perwira Menengah TNI AD yang menunjukkan self esteem memberikan peranan sekitar $41 \%$ terhadap aspek fungsi sosial dari penyesuaian diri, self esteem juga memberikan peranan sebesar $78 \%$ terhadap aspek moral, dan $41 \%$ terhadap aspek kesehatan fisik. Self-esteem akan memproyeksikan cara pandang individu terhadap situasi lingkungannya, dan akan mempengaruhi pula bagaimana ibu berespon dalam menyesuaikan diri dengan perubahanperubahan dalam kondisinya yang sudah tidak bekerja lagi. Penelitian ini menunjukkan bahwa self-esteem memiliki kontribusi yang cukup besar terhadap penyesuaian diri pada ibu berhenti bekerja.

Terjadinya self esteem yang tinggi dan penyesuaian diri yang baik juga disebabkan oleh dukungan sosial dari keluarga. Dalam penelitian yang peneliti lakukan mayoritas ibu menjawab keputusan untuk berhenti 
bekerja didukung oleh suami sebesar $67,1 \%$ dan yang kedua adalah dukungan dari ibu sebesar 21,4\%. Hasil ini sejalan dengan penelitian Savin (dalam Sari, 1998) yang menunjukkan bahwa pemberian dukungan sosial yang tepat ketika menghadapi masalah akan meningkatkan harga diri, penyesuaian diri, dan mengurangi stres.

Menurut Sarason, Levine \& Bashaum (dalam Apollo, 2007) orang-orang yang mendapat dukungan sosial tinggi akan mengalami hal-hal positif dalam hidupnya, mempunyai self esteem yang tinggi dan self concept yang lebih baik, serta kecemasan yang lebih rendah. Orang-orang ini juga memiliki pandangan yang optimis terhadap kehidupan dan pekerjaannya karena yakin akan kemampuannya, dibanding orangorang yang rendah dukungan sosialnya. Orang yang kurang mendapat dukungan sosial cenderung merasa tidak puas dengan kehidupan dan pekerjaannya.

Pada penelitian ini, mayoritas ibu memiliki self esteem dan penyesuaian diri yang baik karena terpenuhinya dukungan sosial dari keluarga dan lingkungan rumah, sehingga menjadi seorang ibu di rumah bukan lagi pekerjaan yang sulit. Meskipun demikian, masih terdapat $1,4 \%$ ibu memiliki self esteem dan penyesuaian diri yang rendah.

Dalam penelitian ini, peneliti juga melakukan uji anova pada variabel self esteem dan penyesuaian diri untuk melihat apakah ada perbedaan pada profil demografis yang peneliti dapatkan.

Hasil dari penelitian ini juga menunjukkan bahwa tidak terdapat perbedaan penyesuaian diri antara lama berhenti bekerja, usia ibu, tempat tinggal, pendidikan terakhir, kondisi kesehatan, kondisi psikologis, kondisi finansial/keuangan, dan jumlah anak dengan penyesuaian diri pada ibu rumah tangga yang telah berhenti bekerja. Namun, pada pendapatan keluarga didapatkan nilai signifikan $\mathrm{p}<0,05$. Apabila nilai signifikansinya $\mathrm{p}<0,05$ maka data tersebut memiliki perbedaan yang signifikan, artinya ada perbedaan penyesuaian diri yang signifikan terkait pendapatan keluarga pada ibu rumah tangga yang telah berhenti bekerja. Dalam penelitian ini, ditemukan bahwa ibu dengan pendapatan keluarga $>5.000 .000$ memiliki penyesuaian diri lebih baik daripada ibu dengan pendapatan keluarga $<2.700 .000$. Artinya dengan pendapatan keluarga yang cukup baik. Ibu dapat menyesuaikan diri dengan baik.

Hasil uji selanjutnya pada variabel self esteem dengan faktor demografis didapatkan hasil bahwa tidak terdapat perbedaan self esteem antara lama berhenti bekerja, usia ibu, tempat tinggal, kondisi kesehatan, pendapatan keluarga, kondisi psikologis, kondisi finansial/keuangan, dan jumlah anak dengan penyesuaian diri pada ibu rumah tangga yang telah berhenti bekerja. Namun, ditemukan pada variabel demografis pendidikan terakhir didapatkan nilai signifikan dengan nilai $\mathrm{p}<0,05$. Artinya terdapat perbedaan yang signifikan terkait self esteem pada ibu. Berdasarkan latar belakang pendidikan terakhir S-1 lebih baik daripada ibu yang memiliki latar belakang pendidikan terakhir SMA. Dalam hal ini, self esteem ibu yang memiliki latar belakang pendidikan menjadi salah satu penentu status sosial ekonomi. Apabila dikaitkan dengan latar belakang pendidikan yang baik maka seseorang akan mampu memiliki self esteem yang baik.

Adapun tuntutan yang berasal dari lingkungan seringkali menimbulkan suatu kondisi stres tertentu yang bisa memperburuk keadaan secara fisik dan emosional para Ibu. Sesuai dengan pendapat Lazarus (dalam Pervin \& Lewis, 1978) bahwa apabila terjadi kesenjangan, ketidakseimbangan antara tuntutan dan kemampuan maka akan timbul suatu keadaan stres. Penanggulangan stres yang dilakukan subjek merupakan bentuk-bentuk dari penyesuaian diri seperti dapat menerima kelebihan dan kekurangan orang lain, mengikuti kegiatan ibu yang aktif di lingkungan rumah yang dapat dilihat dari alat ukur penyesuaian diri yang peneliti lampirkan.

Penyesuaian diri menurut Haber \& Runyon (1984) meliputi lima aspek, yaitu persepsi yang akurat terhadap realita, kemampuan untuk mengatasi stres dan kecemasan, self image yang positif, kemampuan mengungkapkan perasaan, hubungan interpersonal yang baik. 
Berdasarkan hasil perhitungan korelasi pada penelitian ini, menunjukkan bahwa self esteem memiliki hubungan yang signifikan dengan kelima dimensi penyesuaian diri. Penyesuaian diri dalam fungsi sosial adalah kemampuan individu untuk mengatasi konflik, frustrasi dan kesulitan-kesulitan dalam diri dan berhubungan dengan relasi sosial. Untuk self image yang positif ditunjukkan bahwa self esteem juga mempengaruhi bagaimana mereka memandang dan menilai dirinya dan kondisi kehidupannya. Ada dari subjek yang menilai diri mereka sebagai ibu yang baik dan mampu beradaptasi, juga terdapat beberapa ibu mengalami kesulitan pada awal berhenti bekerja.

\section{SIMPULAN DAN SARAN}

\section{Simpulan}

Hasil penelitian menyatakan bahwa terdapat hubungan positif yang signifikan antara self esteem dan penyesuaian diri terhadap peran sebagai ibu rumah tangga pada ibu berhenti bekerja di Jakarta. Dengan demikian, bisa dikatakan bahwa semakin tinggi self esteem seorang ibu maka akan semakin adaptif pula proses penyesuaian diri terhadap perannya sebagai ibu rumah tangga dan sebaliknya semakin rendah self esteem seorang ibu maka akan semakin kurang mampu untuk menyesuaikan diri terhadap perannya sebagai ibu rumah tangga.

\section{Saran}

Saran untuk pengembangan penelitian agar dilakukan penelitian lanjutan untuk rentang usia yang berbeda. Bagi peneliti selanjutnya agar dapat mengadakan penelitian yang berhubungan dengan self esteem ibu rumah tangga yang tidak bekerja tidak hanya ditinjau dari aspek penyesuaian diri saja, namun aspek lain seperti dukungan sosial. Anggota keluarga juga dapat membantu dalam membangun self esteem yang baik pada ibu rumah tangga karena dapat diprediksi bahwa self esteem berperan dalam membangun penyesuaian diri mereka yang nantinya akan berdampak pada kesejahterahan keluarga.

\section{DAFTAR PUSTAKA}

Ananda, R.M. (2013). Self-esteem antara ibu rumah tangga yang bekerja dengan yang tidak bekerja. Jurnal Psikologi, 1(1).

Apollo. (2007). Hubungan antara konsep diri dengan kecemasan berkomunikasi secara lisan pada remaja manasa. Jurnal Psikologi, l(1), 17-32.

Azwar, S. (2004). Penyusunan skala psikologi. Yogyakarta: Pustaka Pelajar.

Baron \& Byrne. (2003). Psikologi Sosial. Jilid 1. Edisi Kesepuluh. Jakarta: Erlangga.

Calhoun, A. (2001). Psychology about adaptation \& human relationship $\left(3^{\text {rd }}\right.$ ed.). New York: Mc Graw-Hill.

Coopersmith, S. (1967). The Antecedents of Self Esteem. San Fransisco: W. H. Freemen.

Corsini, R.J. (2002). The Dictionary of Psychology. New York: Brunner/Mazel.

Davidoff, L.L. (1991). Psikologi Suatu Pengantar. Edisi 2. Jilid 2. Jakarta: Penerbit Erlangga.

Desiningrum, R.D. (2012). Hubungan selfesteem dengan penyesuaian diri terhadap masa pensiun pada pensiunan perwira menengah TNI AD. Jurnal Psikologi, 7(1), 14-20.

Dwijayanti, J.E. (1999). Perbedaan motif antara ibu rumah tangga yang bekerja dan yang tidak bekerja dalam mengikuti sekolah pengembangan pribadi dari Jhon Robert Powers. Media Psikologi Indonesia, 14(55).

Haber, A., \& Runyon, R. (1984). Psychology of adjustment. Illinois: The Doesey. 
Heatherton, T. F., \& Polivy, J. (1991). Development and validation of a scale for measuring state self-esteem. Journal of Personality and Social Psychology, 60, 895-910.

Heatherton, T.F., \& Wyland, C. (2003). Assesing Self Esteem. In S. Lopez dan R. Synder, (Eds). Assesing Positivme Psychology. (pp. 219-233). Washington, DC: APA.

Hermawati, N. (2011). Hubungan antara self-esteem dengan konformitas mahasiswa psikologi yang pernah mengikuti organisasi. Skripsi: Universitas Bina Nusantara.

Hidayanti. N.H (2014). Hubungan Antara Body Image dengan Penyesuaian Diri Pada Remaja Overweight di Jakarta dan Bekasi serta Tinjauanya dalam Islam. Skripsi. Jakarta: Universitas Yarsi.

Hoyer, W. J., \& Roodin, P. A. (2009). Adult Development and Aging $6^{\text {th }}$ ed. New York: McGraw Hill.

Ibadiah. (2016). Ibu Rumah Tangga Sekaligus Wanita Karir. Diakses pada tanggal 13 Mei 2018 dari http://perwakilan.babelprov.go.id/con tent/ibu-rumah-tangga-sekaliguswanita-karir?qt-artikel=2

Indrawati, E. S., Fauziah, N. (2012). Attachment Dan Penyesuaian Diri Dalam Perkawinan. Jurnal Psikologi Undip, 11(1).

Irene, Lidya \& Hadi W. (2013). Perbedaan tingkat kemandirian dan penyesuaian diri mahasiswa perantauan suku Batak ditinjau dari jenis kelamin. Jurnal Psikologi, 1(2).

Koran, SI. (2010). Kembali Bekerja atau Jadi Ibu Rumah Tangga? Diakses pada tanggal 21 November 2017 dari https://lifestyle.okezone.com/read/20 10/08/30/196/368060/kembalibekerja-atau-jadi-ibu-rumah-tangga
Laswell, Harold D., \& Abraham Kaplan. (1950). Power and Society, New Haven, Yale University Press, USA.

Maisya, D. (2014). Studi mengenai stres dan coping stres pada ibu rumah tangga yang tidak bekerja. Skripsi: Universitas Padjajaran.

Markus, H. R., \& Kitayama, S. (1991). Culture and the self: Implications for cognition, emotion, and motivation. Psychological Review, 98, 224-253.

Markus, H. R., \& Kitayama, S. (1994). A collective fear of the collective: Implications for selves and theories of selves. Personality and Social Psychology Bulletin, 20, 568-579.

Martin, G. L., \& Osbsorne, J. G. (1997). Psychological Adjustment Everyday Living. New York: Prentice Hall.

Papalia, D. E., Olds, S. W., \& Feldman, R. D. (2009). Human development: Perkembangan manusia edisi 10 buku 2. Jakarta: Salemba Humanika.

Pervin, L. A., \& Lewis, M. (1978). Perspective in Interactional Psychology. New York: Plenum Press.

Ponzetti, J.J. (2003), International Encyclopedia of Marriage and Family, $\quad 2^{\text {nd }}$ ed., Macmillian Reference, New York.

Putri, S. A. P. (2010). Penyesuaian diri pada remaja obesitas ditinjau dari kematangan emosi dan jenis kelamin. Informatika, 1(2), 92-104.

Santrock, J. W. (2005). Life-span development. USA: McGraw-Hill Humanities Social.

Sari, N. P. (1998). Hubungan antara dukungan sosial dengan kepercayaan diri pada remaja Yogyakarta. Skripsi: Fakultas Psikologi UGM. 
Schneiders, A. (1964). Personal adjustment and mental health. New York: Rinehart \& Winston.

Sitorus, L. I. S., \& Wiryosutomo, H. W. (2013). Perbedaan tingkat kemandirian dan penyesuaian diri mahasiswa perantauan suku batak ditinjau dari jenis kelamin. Character, l(2).

Smet, B. (1994). Psikologi kesehatan. Jakarta: PT Grasindo.

Sukmana. (1995). Tanggungjawab Wanita dalam Kehidupan Rumah Tangga. Suara Karya VIII, hal: 1-6. Jakarta: Pusat Informasi Wanita dalam Pembangunan PDII-LIPI.

Wardani, Z. (2015). Hubungan social support dan work-family conflict pada ibu yang bekerja sebagai unit manajer asuransi di PT. "X" Bandung. Skripsi: Universitas Kristen Maranatha.

Wicaksono, R. (2011). Perempuan Bekerja (Sebuah Dilema Perubahan Zaman). Diakses pada tanggal 21 November 2017 dari https://www.kompasiana.com/renaldi .wicaksono/perempuan-bekerjasebuah-dilema-perubahanzaman_5500b32f8133111918fa7c0b.

Wolfman, B.R. (1988). Peran Kaum Wanita. Yogyakarta: Kanisius. 